December 2010

\title{
An Analysis of Perspectives on the Office of the Special Adviser on the Prevention of Genocide
}

Aidan Hehir

Follow this and additional works at: https://digitalcommons.usf.edu/gsp

\section{Recommended Citation}

Hehir, Aidan (2010) "An Analysis of Perspectives on the Office of the Special Adviser on the Prevention of Genocide," Genocide Studies and Prevention: An International Journal: Vol. 5: Iss. 3: Article 4.

Available at: https://digitalcommons.usf.edu/gsp/vol5/iss3/4

This Articles is brought to you for free and open access by the Open Access Journals at Digital Commons @ University of South Florida. It has been accepted for inclusion in Genocide Studies and Prevention: An International Journal by an authorized editor of Digital Commons @ University of South Florida. For more information, please contact digitalcommons@usf.edu. 


\title{
An Analysis of Perspectives on the Office of the Special Adviser on the Prevention of Genocide
}

\author{
Aidan Hehir \\ Department of Politics and International Relations, \\ University of Westminster
}

In April 2004, on the tenth anniversary of the Rwandan Genocide, the UN secretarygeneral established the Office of the Special Adviser on the Prevention of Genocide (OSAPG). While the OSAPG has been hailed in some quarters as major institutional reform of significant importance, there has been no focused academic analysis of its mandate and work to date. This article addresses this gap and is based on a series interviews conducted with prominent members of the OSAPG itself and experts in the field of human rights. The article analyzes the differing perspectives on the OSAPG and identifies the major institutional weaknesses, methodological failings, and ongoing challenges facing the OSAPG as cited by the interviewees. While there is clearly broad-though not universal-support for the establishment of the OSAPG, there are a number of factors, both endogenous and exogenous, which appear to have limited the influence of the OSAPG, and it is not clear whether the office, as presently conceived, can realize the task it has been mandated.

Key words: genocide prevention, Special Adviser on the Prevention of Genocide, United Nations, Security Council, Francis Deng, responsibility to protect (R2P)

\section{Introduction}

The Holocaust states have often committed themselves to preventing genocide, most clearly through the 1948 Genocide Convention. Active support for the implementation of substantive reforms and initiatives aimed at achieving this goal, however, has been less forthcoming. The refrain "Never Again!," so often solemnly articulated since the Holocaust, has often appeared as little more than an empty slogan when contrasted with the glacial pace of reform and the international community's erratic response to instances of alleged and clear genocide in the modern era. There has been, as Thomas Weiss noted, "a dramatic disconnect between political reality and pious rhetoric." 1

The establishment of the Office of the Special Adviser on the Prevention of Genocide (OSAPG) in 2004, however, constitutes a definite structural innovation within the UN architecture specifically focused on helping to realize the "Never Again!" promise. The OSAPG has been described as "pioneering new approaches to genocide prevention that represent an important part of the intellectual history of preventative diplomacy at the UN" and "an authentic basis for hope that the UN may move gradually toward fulfillment of its potential." 2 The OSAPG is, therefore, of great importance not only for scholars working on genocide, but for all those

Aidan Hehir, "An Analysis of Perspectives on the Office of the Special Adviser on the Prevention of Genocide," Genocide Studies and Prevention 5, 3 (December 2010): 258-276. (C) 2010 Genocide Studies and Prevention. doi:10.3138/gsp.5.3.258 
concerned with the evolution of the UN and specifically its mechanisms for addressing intrastate humanitarian crises.

Despite this importance, to date there has been a dearth of academic inquiry into the creation and role of the OSAPG, reflected in the paucity of references to the office in academic literature. This article aims to help fill this gap in the literature by providing an analysis of perceptions of the OSAPG's role to date and the barriers to its efficacy, based on a series of face-to-face interviews conducted during the summer of 2009. The intention is twofold: first, to provide the first academic analysis of perspectives on the OSAPG from practitioners and experts in the field of human rights, and second, to analyze the OSPAG's own perspective on its role and its response to the criticisms leveled against it.

This article initially provides an overview of the establishment of the OSAPG and the nature of the interviews conducted. There follows a conceptual analysis of the OSAPG, assessing perceptions on both whether it normatively constitutes a significant innovation and how it can best add value to the existing UN system. The subsequent section focuses on empirical issues, namely, the profile of the OSAPG, its relationship with the UN and specifically the Security Council, and the nature of its work. The final section assesses the issues identified as constituting barriers to the future success of the OSAPG.

\section{Background to the OSAPG}

The genocide in Rwanda in 1994 was the catalyst for a process of self-reflection within the UN, which was derived from a general consensus that the UN system had failed to respond in a timely and effective manner to this tragedy. ${ }^{3}$ The UN's inquiry into the genocide identified gaps in the early warning capacity of the organization and called for "an action plan to prevent genocide" aimed at "improving early warning." 4 This was re-emphasized by Secretary-General Kofi Annan in a 2001 report when he advocated establishing a new office devoted to prevention. ${ }^{5}$ In April 2004, on the tenth anniversary of the Rwandan genocide, Kofi Annan launched his "Action Plan to Prevent Genocide," which included the establishment of the OSAPG. While this was certainly not the first time the UN had addressed the issue of preventing genocide, the establishment of this office was unprecedented. David Hamburg notes: "It was the first time any prevention professional had been appointed at such a high level ... [and] the first time that a unit focusing specifically on genocide prevention had ever been created at the UN."6

The mandate of the OSAPG, contained in a letter from the secretary-general to the Security Council on 12 July 2004, noted,

The Special Adviser will (a) collect existing information, in particular from within the United Nations system, on massive and serious violations of human rights and international humanitarian law of ethnic and racial origin that, if not prevented or halted, might lead to genocide; (b) act as a mechanism of early warning to the SecretaryGeneral, and through him to the Security Council, by bringing to their attention potential situations that could result in genocide; (c) make recommendations to the Security Council, through the Secretary-General, on actions to prevent or halt genocide; (d) liaise with the United Nations system on activities for the prevention of genocide and work to enhance the United Nations capacity to analyse and manage information relating to genocide or related crimes. ${ }^{7}$

Initially, Juan Mendez, an Argentinean human rights lawyer, was appointed Special Adviser and the role was part-time. In May 2006, Kofi Annan established an 
Advisory Committee to support the work of the OSAPG. On 27 May 2007, Francis Deng, former Representative of the United Nations Secretary-General on Internally Displaced Persons, was appointed Special Adviser and, in August 2007, the OSAPG was made a full-time position and the status of the Special Adviser was upgraded to Under-Secretary-General.

Rather than rely on the few second-hand sources that deal only tangentially with the OSAPG, ${ }^{8}$ or the OSAPG's own reports, I conducted a series of interviews in August 2009 to evaluate opinion as to the utility of the office. ${ }^{9}$ The aim of these interviews was to gather information on the OSAPG both from those working within the OSAPG and those outside the OSAPG who work on issues directly related to its mandate. In the first category I interviewed Dr. Francis Deng, the Special Adviser; Professor David Hamburg, Chairman of the OSAPG Advisory Committee; and Maria Stavropoulou and Castro Wesamba, both Political Affairs Officers within the OSAPG. In the second category I interviewed Steve Crawshaw, Human Rights Watch's United Nations Advocacy Director; Heather Sonner from the International Secretariat of the Institute for Global Policy; Sapna Chhatpar Considine, Project Manager with the International Coalition for the Responsibility to Protect; Nicola Reindorp, Director of Advocacy at the Global Centre for the Responsibility to Protect; and Professor Thomas Weiss, Director of the Ralph Bunche Institute for International Science, which is affiliated with the Central University of New York. The following analysis reflects the perspectives of these interviewees and draws out generic themes related to the OSAPG's normative raison d'être, role to date, and future prospects.

\section{Perspectives on the Concept of a Special Adviser on the Prevention of Genocide}

There are very few people who, in principle, oppose preventing genocide. Broad support for genocide prevention, of course, need not readily translate into support for the creation of a particular UN office or indeed the OSAPG itself. There are those, however, who argue that while genocide prevention is a nice idea, it is simply not possible to predict the occurrence of genocide with any kind of accuracy. ${ }^{10}$ Others argue that even the best genocide early warning system will be of little to no use as the international community's reaction to suspected or actual genocide is typically too little, too late. While the horror of the genocide in Rwanda in 1994 compelled many to call for improved early warning systems and greater international engagement in states evidencing signs of instability, many drew significantly different conclusions. Given that the international community had brokered the Arusha Accords-deemed by many to have been a catalyst in the eventual carnage ${ }^{11}$-and also that there were many international observers, including the UN force UNAMIR, in Rwanda prior to the outbreak of the violence, some have argued that the genocide cannot be cited as evidence in support of the idea that early intervention and international engagement is necessarily a good thing. ${ }^{12}$

It is not the intention of this article to engage with this argument. ${ }^{13}$ Clearly, those who are skeptical about early intervention and preventative diplomacy generally will be unlikely to view the establishment of the OSAPG as a useful development. A more illustrative means of gauging perceptions of the OSAPG's utility is derived from garnering the views of those who believe that preventative diplomacy and international engagement generally are, in principle, good ideas, hence the choice of interviewees outside the OSAPG itself. 
Heather Sonner, from the International Secretariat of the Institute for Global Policy, noted that her organization wishes to have "a very collaborative relationship with the Special Advisor's office ... we very much want to support the mandate and what they do." Sonner argued that the secretary-general was tasked with maintaining a generally cordial relationship with all member states. The Special Adviser, however, would have the freedom to "speak out on such a sensitive issue as genocide and ... sound the alarm." 14 This view was echoed by Steve Crawshaw from Human Rights Watch, who identified "the wakeup call potential" of the OSAPG as being "very important."15 Similarly Nicola Reindorp, Director of Advocacy at the Global Centre for the Responsibility to Protect, stated, "Has [the OSAPG] got an important and valuable role and has the original concept behind it still got value? Absolutely." 16 A key aspect of the "valuable role" of the OSAPG, according to Reindorp, was that it would, "make it more politically costly for any policy maker to fail ... to take action in a particular way," and that the existence of the office meant "[there are] people responsible to ensure that parts of the [UN] bureaucracy are watching for warning signs and driving discussion around policy options." 17

The OSAPG does not have a significant presence on the ground in trouble spots around the world, nor has it established a new means of gathering information. Rather, it aims to "filter information." 18 Yet analyses of the genocide in Rwanda in 1994 have noted that the most outrageous aspect of the UN response was the fact that information was readily available and alarm bells were sounded, most infamously Romeo Dallaire's cable on 11 January 1994 warning that he had uncovered plans for mass murder and had information about the location of weapons caches. ${ }^{19}$ Establishing an office to manage information about impending genocide may thus be seen as a solution to a problem that has not really been of major import, certainly when compared to the problem of mobilizing political will among the five permanent members of the Security Council (the P5) to take timely and effective action. Crawshaw argued, however, that "[in 1994] there wasn't a lack of information but there was a lack of those who had information, who were able to cut like a knife through the system." 20 The OSAPG, he suggested, had the potential to serve as this fast track. On this issue Sonner noted that while there were certain offices within the UN that were already charged with dealing with gathering information related to the prevention of genocide-in particular the High Commissioner for Human Rights-there was no single spokesperson mandated specifically to focus on genocide prevention and thus the OSAPG brought a sharper focus to the issue. Sonner argued that the OSAPG would be able to "prevent the hyper politicisation of that information as it moves up the chain within the Secretariat, which we did see in the case of Rwanda." 21 Reindorp claimed that it would be a "real exaggeration to suggest that the appointment of one person and a couple of people is going to revolutionize the response to genocide." Nonetheless, this attempt "to plug one little piece of the gap in the capacity of the UN secretariat, which itself is one tiny, tiny piece in the whole prevention of genocide architecture" was, she claimed, "significant," though the OSAPG should not be seen as "a kind of a panacea." 22

Within the OSAPG, the question of the office's added value was accepted as being "a valid concern." 23 Francis Deng acknowledged that there was a plethora of sources of information and that the OSAPG was not going to add significantly to the detection of warning signs and did not constitute "anything dramatically new." 24 Nonetheless, he argued that the significance of the OSAPG derived from the fact that, unlike NGOs, "[the OSAPG is a] UN entity, which was agreed upon as a result of collective thinking about what the UN should be doing to respond to 
this issue. [It is] a spotlight within the system which is well equipped and capacitated, it can mobilise these resources." 25 Deng recalled that prior to the Rwandan genocide, Bacre Ndiaye, then UN Special Rapporteur on Extrajudicial, Summary, or Arbitrary Executions, wrote a report that he submitted to the UN warning about the likelihood of massive violence in Rwanda. This report, Deng noted, was lost in the UN bureaucracy. ${ }^{26}$ Deng claimed, "If Ndiaye's report had come to a focal point within the UN system that was charged to make use of such information, to rally forces, to alert the Secretary-General to inform the Security Council, that perhaps would have been more effective." 27 The OSAPG was evidently now acting as this "focal point with the UN system" and thus ostensibly constituted a significant reform of the existing system. Likewise Maria Stavropoulou, Political Affairs Officer within the OSAPG, argued that the very existence of the OSPAG meant that if action was not taken and genocide occurred, the OSAPG would be able to apportion blame. $^{28}$

This broad support for the establishment of the OSAPG and endorsement of its utility was not shared by all. Professor Thomas Weiss asserted, “[I]it's not a real job, it's not something you can really do anything about from the inside at this point in time ... I think it would make much more sense to keep this as a focus or a part of the High Commission for Human Rights and keep it live, but not expect it to go anywhere because I don't think it will." 29 Weiss noted that this was a view shared by Gareth Evans, who expressed similar concerns at a meeting of the OSAPG Advisory Committee. ${ }^{30}$ In response to Evans's criticism of the OSAPG, Weiss claimed, "[David] Hamburg went through the ceiling, Francis [Deng] went through the ceiling but I actually think that they just don't want to hear how few clothes the emperor has." ${ }^{31}$ Additionally, while the representatives of the NGOs interviewed were broadly supportive of the office's raison d'être, they all expressed significant concerns about the methods of the Special Adviser. These concerns, explored in the next section, suggested that the OSAPG's potential utility had not been achieved, rendering the office largely impotent.

\section{Assessing the Role of the OSAPG to Date}

The OSAPG has yet to achieve a high profile; according to Sonner, "there is still a significant challenge in making people aware that the office exists." 32 It has attracted very little attention within academia, and even within the UN system, it has been overlooked at times. Stavropoulou noted that the OSAPG was not invited to a meeting of a UN inter-agency framework team for conflict prevention. She recalled, "The office had to take the initiative to say, 'We would like to be part of this.' This happened not just with this framework but within a couple of other fora as well. There was no objection, nobody said, 'We don't think you should be part of that meeting,' there was never any objection but also there was no automaticity." 33 It is significant that an office charged with such an important mandate established over five years ago would be overlooked in this way and it is indicative of the OSAPG's low profile.

To some extent, the OSAPG's low profile derives from the initial status of the office. David Hamburg noted that prior to his appointment as Special Adviser, Juan Mendez had accepted a full-time position as a president of the International Centre for Transitional Justice. According to Hamburg, while Kofi Annan appointed Mendez in the belief that he would work full-time, Mendez believed the position was parttime, involving "at the most, a day a week." Hamburg recalled, "Well then, we had to make the best of it. We didn't want to embarrass Kofi, we didn't want to 
embarrass Mendez, and so we decided, 'Well, let's say we're going to start very small and experimentally." 34 This confusion, and the initial part-time nature of the role during Mendez's tenure, understandably influenced the OSAPG's productivity. When Mendez stepped down and was replaced by Deng, the position was quickly made full-time, although, according to Hamburg, "[The UN] budget committee gave [Deng] nothing," with the result that Deng had to make do with a skeletal staff for the first year of his tenure. ${ }^{35}$ Deng acknowledged that he spent most of his initial twelve months trying to generate funding and recruit staff rather than actively working to fulfill his mandate. ${ }^{36}$

In addition to this issue of capacity, a number of other explanations were cited as reasons for the OSAPG's low profile. Stavropoulou noted that "because of its type of mandate and the type of work it does, [the OSAPG] cannot be a very 'productive' office. We do not put notes and reports on our website like others; we simply can't. Politically it's impossible." Additionally, she suggested that within the UN, "there is a bit of a proliferation of separate offices, entities, units, and so forth, and not all are well known." 37 This is certainly true; nevertheless, it is curious that an office that is tasked with addressing such an emotive issue, which resonates so widely and attracts so much attention, should be so anonymous. ${ }^{38}$

All those interviewed not directly connected to the OSAPG identified Deng's style as a key factor in the failure of the OSAPG to achieve prominence. Weiss noted that the few press statements realized by the OSAPG had been largely devoid of significant content and asserted, "I think Juan Mendez did more in 5\% of his time than Francis does in $100 \%$ of his." Weiss claimed that Deng had "moved very quickly into becoming a UN bureaucrat," suggesting he had decided to maintain cordial relations with key actors in the UN and the major states. Deng's previous trail-blazing work on internally displaced, Weiss argued, was a function of his position at the time as a Senior Fellow at the Brookings Institute, which gave him more freedom. Regarding Deng's new role, Weiss stated, "He's in a real comfort zone; the secretarygeneral's not pushing him to do more, his [Advisory] Committee isn't pushing him to do more, states would just as soon [prefer] he'd keep quiet." Weiss claimed that the current UN Secretary-General Ban Ki-Moon "doesn't want any noise or any waves," while "Francis [Deng] doesn't want anybody to be angry at him any of the time." The combination of these approaches meant "[the OSAPG] is so behind the scenes that it's invisible." 39

Sonner agreed that there were many within the NGO community who called for Deng to have a much more public profile. She argued that more should have been done to date in terms of public diplomacy and claimed that the OSAPG needed to engage in a "substantial amount of outreach." 40 Reindorp acknowledged that the OSAPG had suffered from a lack of resources, and while she accepted that Deng's preference was for quiet diplomacy, she argued that "there hasn't been as much dynamism in the office, even in doing that." 41

Deng acknowledged that he is committed to a "quiet approach" and observed that, "obviously, you don't see the results of the quiet approach as much." 42 Accepting that there were many within the NGO community who disagreed with his approach, Deng defended his style by claiming it had proved its effectiveness during his time as representative of the United Nations Secretary-General on Internally Displaced Persons. He claimed that, "if I were to be seen as crying out loud, naming and shaming, talking about such a sensitive issue ... I would not be invited by countries, doors would be closed, and I don't see how I can help people if I cannot even go and see the country and engage the governments in a constructive dialogue." 43 Deng 
further argued that the results of his efforts were effectively doomed to invisibility for two reasons: First, successful preventative action necessarily stops something becoming a major issue and thus is less likely to attract attention. Second, behindthe-scenes diplomacy is by definition conducted in private and cannot be publicized if it is effective. Continuing, Deng noted, "The British ambassador was telling me just the other day, 'You have really made an impact by approaching your mandate in a non-threatening way,' but that is not visible to people. Nobody's going to speak about it unless you go round and perhaps question member states about what they think about the work we're doing." 44 There is clearly a degree of logic to Deng's defense of his methods. Nonetheless, when I asked Deng and his staff to identify where the OSAPG had had the greatest positive impact, which may not have been apparent to outsiders, their responses were evasive. ${ }^{45}$

The manner in which Deng has chosen to pursue his mandate is clearly of some concern. This is made all the more significant by virtue of the fact that there was general consensus that the potential utility of this office was, almost uniquely, a function of the Special Adviser's capacity to speak out. Crawshaw argued that the OSAPG had to be outspoken to have any real effect and stated, "Once you've got that job title on your business card, you have to accept that is the job title on your business card and not everybody's going to like you. So you can stop thinking that you can be everybody's best friend. You won't be and that's impossible.... Yes, it's a post which requires diplomacy in many contexts, but it also requires very robust speaking." 46 Sonner noted that her organization initially supported the OSAPG because they believed the office would be "making the tough calls and really putting the pressure on member states to take action in situations that look like they're moving towards genocide," and thus they were disenchanted with Deng's approach. ${ }^{47}$ Reindorp asserted that the OSAPG had to do more than exclusively engage in behind-the-scenes work; she noted, "Have you got the person in the position that is best able to juggle the challenges between being the whistle-blower and being the advocate with governments? I don't think so." 48 Staff at the OSAPG, perhaps unsurprisingly, rejected this assertion; Stavropoulou argued, "a public statement can shut that many more doors in the short term, and in the long term make the mandate less effective, and I think NGOs don't always realize that." 49 NGOs, she claimed, tend to evaluate activity on the basis of the number of statements an office had made, and in the case of the OSAPG, this approach overlooked much of its work.

Deng and his staff were also keen to highlight the fact that their capacity to make public statements was dependent on the assent of the secretary-general. Stavropoulou recalled that there were times when the Special Adviser had wanted to speak out, but "it wasn't always possible" because of opposition from the secretarygeneral. ${ }^{50}$ Deng similarly stated,

Another very important thing that people miss is I am an arm of the secretarygeneral and everything I do, even when I want to make a statement or a press release or an op-ed, has to be cleared with the office of the secretary-general and very often, in fact on two or three occasions, they advised me against saying anything ... on the Sudan, on Sri Lanka, on Myanmar. I think people miss this when they think I have my own autonomous standing ... I'm not an independent voice of humanity; I am a tool of the secretary-general. ${ }^{51}$

While this subservience to the secretary-general, himself widely considered overly cautious, appears to support Weiss's view on the impact of Deng's personality, Castro Wesamba, Political Affairs Officer within the OSAPG, argued that the OSAPG did 
not acquiesce with the secretary-general's caution in every instance, and noted that there were occasions when "we have really come out very strongly within the UN system and said, 'There's no way the Special Adviser's going to keep quiet about this." 52 Despite this apparent unwillingness to tow the line in every case, it is difficult to identify anything controversial or even strongly-worded in any of the statements released by the OSAPG. It seems clear that the combination of a very cautious secretary-general and a Special Adviser, who by nature seeks to maintain cordial relations with everyone, has had an impact on the public profile of the OSAPG.

While the relatively low profile of the OSAPG was overwhelmingly attributed to the approach taken by Deng, Sonner did highlight another possible explanation. She speculated that Deng's caution had much to do with the fact that his predecessor had once been embarrassingly barred from addressing the Security Council. ${ }^{53}$ This incident occurred on 10 October 2005 when, according to Hamburg, the then US Ambassador to the UN, John Bolton, literally marshaled Mendez out of the room before a meeting of the Council. ${ }^{54}$ Clearly this public denigration of the OSAPG did little to enhance its status and, as Sonner suggests, there appears to be evidence that Deng was influenced by this incident. He stated that "my approach, which some NGOs were uneasy with, is not to press [the Security Council]. When I came on board I said, 'Look, if I come out loudly knocking at the door and the door is closed, what good is it? I'm just going to create tension between my office and the Security Council." 55 Deng has certainly not formally engaged with the Security Council as much as many would like, with Weiss and Sonner particularly critical of his reluctance to do so. Crawshaw observed that Mendez had been highly critical of the Security Council's ability, and evident willingness, to block the Special Adviser from addressing meetings of the Council. ${ }^{56}$ In his final report as Special Adviser, Mendez advised that the mandate of the OSAPG be strengthened to ensure that the right to address the Council be clarified. This amendment to the mandate has not occurred..$^{57}$

This capacity to address the Council has been cited as one of the OSAPG's most significant powers. ${ }^{58}$ The reluctance on the part of members of the Security Council, both permanent and non-permanent, to allow the Special Adviser access clearly undermines the potential of this aspect of the OSAPG's mandate, and thus, in practice, the mandate of the OSAPG is not a mechanism that ensures warnings are always conveyed to the Security Council. ${ }^{59}$ Nonetheless the potential for the Special Adviser to address the Security Council is cited by OSAPG staff as "a major achievement in itself," which differentiates the OSAPG from NGOs and other UN bodies. 60 Stavropoulou argued that while Deng had not pushed to exercise this privilege, "there are different ways of engaging the Security Council. It doesn't have to be through the submission of a report in a formal way or through a formal hearing. It can be through informal contacts with the members, informal contact with the President. There are many different ways of communicating in a fashion that won't be threatening and therefore will result in rejection." 61 Deng, indeed, suggested that formally addressing the Council was of limited utility. He stated, "Every time an issue is brought to the Security Council, you can predict ... how Russia, China, and the others will vote. This is another consideration when it comes to my relationship with the Security Council; if you go there and say, 'I am here concerned about what's happening in this or that country,' not only are you raising the stakes but you're also generating controversy because you are going to get one member or another of the P5 to defend that country." 62 In addition to this question about the utility of 
addressing the Council, there is the issue of the novelty of this provision. It is indeed true that there are few offices within the UN, and fewer outside it, that can address the Council directly. Yet, it is not the case that without this privilege the perspectives of certain groups can never be heard at Council meetings. Under Article 99 of the Charter, the secretary-general can automatically address the Council; while this provision is rarely used, it is conceivable that the secretary-general may bring details of a report by a particular UN office or even an NGO to the Council's attention. In this sense, the capacity of the OSAPG to present to the Council may not be as significant as it first appears. I put this to the staff at the OSAPG; Wesamba replied, "Okay, yes, [a report by an NGO] can be raised. The secretary-general can brief the Security Council directly about Situation X, of which the information has come from the Red Cross or some other NGO." He added, however, that a report from the OSAPG would be different because "it creates responsibilities ... I think it creates expectations and that's the difference." Given that the Council had agreed to the establishment of the OSAPG, he argued, a briefing by the Special Adviser "creates obligations." 63

The fact that the Security Council has been less than enthusiastic about hearing reports from the OSAPG is not altogether surprising. What was perhaps more surprising was that OSAPG staff, including the Special Adviser himself, claimed that there was opposition to the OSAPG from within the UN bureaucracy itself. Deng asserted that there were a number of times when he sought to have an input into the UN's response to a certain intrastate situation and "the first line of resistance was from our own people." Deng stated that as his office did not have independent information-gathering capacity, the OSAPG was reliant on other offices within the UN to provide them with information. He noted, however, that "there are entities, even within the UN, that consider this type of information confidential and they are guarding their own interests ... We are supposed to get the information from within the UN, primarily from within the UN. Yet we get more information from outside the UN because NGOs are willing, and scholars are willing to give us what they know. The system itself is not that collaborative." 64 Deng specifically cited the cases of the Democratic Republic of Congo in 2008 and Sri Lanka in 2009 as instances when his involvement was greeted with hostility from within the UN system. Deng recalled that he became particularly frustrated when his involvement in Sri Lanka was questioned and he told a meeting of the secretary-general and his senior staff, "You say that the office has no say? When will it ever be in a position to say anything about any country?"65 Both Deng and his staff stated that their presence at UN meetings on a particular country situation invariably led to raised eyebrows as other offices assumed that the OSAPG would concern itself only with instances of genocide. ${ }^{66}$ In fact, the opposite is the case; the OSAPG, as one might indeed guess from the title, is concerned with preventing genocide rather than identifying it. In fact, the Special Adviser is not mandated to decree that genocide is taking place.

While it may at first seem curious that the UN system itself has proved to be reluctant to engage with the OSAPG, and has at times evidently been hostile toward it, this may be more comprehensible when one assesses the nature of bureaucracies in general. Michael Barnett's highly critical analysis of the UN's response to the Rwandan genocide is notable for his claim that, while the UN's response was unquestionably deeply flawed, it was, "grounded in ethical considerations." 67 Clearly these considerations did not privilege the suffering Tutsis, and thus the basis for the ethical considerations that informed the decision to react to the genocide in such a manner must be found elsewhere. Barnett argues that the UN, like all 
bureaucracies, has developed "a discourse and formal and informal rules that shape what individuals care about and the practices they view as appropriate, desirable, and ethical in their own right." 68 Thus, in 1994 the priority, perversely, within the UN was not the plight of the Tutsis, but rather "the health of the UN." 69 The growth and suffocating pervasiveness of the bureaucratic ethical code creates a situation where those charged with serving certain individuals and groups outside the organization actually de-prioritize this formal role in favor of a determination to preserve the integrity of the system. Hence, the establishment of the OSAPG can be seen as constituting a challenge to the status quo within the UN bureaucracy, and it is, therefore, entirely predictable that those people long socialized into the UN bureaucratic mindset and its insular priorities would seek to protect the status quo and undermine and isolate the OSAPG. Of course, this hostility to the OSAPG, and indeed any ostensible challenge to the status quo and prevailing bureaucratic culture, will dissipate if the OSAPG itself internalizes the dominant cultural norms and ethical priorities. As explored later in this article, there is evidence to suggest that the OSAPG has already sought to integrate with the existing system rather than act as a challenge to it. Indeed, according to Thomas Weiss, "[Deng has] moved very quickly into becoming a UN bureaucrat, 'recognizing all the constraints that exist,' blah, blah, blah, and he is no longer on the outside."70

The misperception about the OSAPG's mandate has had an impact on its relations with states as well as other UN offices. It is perhaps understandable that states will be somewhat resistant to engaging with "The Special Adviser on the Prevention of Genocide" given the negative implications that will invariably arise. Indeed, Weiss remarked, "If you were coming to my country and you said, 'I'm the Adviser on the Prevention of Genocide,' the idea that I would welcome you with open arms is clearly not a solid place to start." 71 Stavropoulou also admitted, "The closer we get to a country, the more difficult it becomes for apparent reasons."72 Paragraph 140 of the 2005 World Summit Outcome Document commits all states to "fully support the mission of the Special Adviser of the Secretary-General on the Prevention of Genocide," although whether this is honored in practice is open to debate. This lack of cooperation appeared to have been evident in late 2008 when a visit to Burundi was canceled when the government claimed to be unable to provide an official to meet the Special Adviser. ${ }^{73}$ Wesamba, however, claimed that "there's not any substantive evidence that states don't like to engage with the Special Adviser" and argued that the case of Burundi was an exception. ${ }^{74}$ Since the establishment of the OSAPG, the situation in Darfur has arguably been the most serious intrastate crises of a potentially genocidal nature. On 19 September 2005, the then Special Adviser Juan Mendez visited Sudan and noted in his report, "The government of Sudan extended its cooperation to me during the course of the visit."75 This suggests that even certain states widely denounced as engaging in genocide appear willing to engage with the OSAPG, or perhaps, it suggests only that the OSAPG has acquired a status that precludes states from being seen to actively ignore it.

Deng noted that his work was also hampered by a reluctance among certain powerful states to engage with the OSAPG, claiming, "those who would be called upon to intervene to stop [genocide], tend to be resistant to discussing this issue."76 Many such states are keen to play down the scale of crises and feel that the OSAPG's presence would attract attention and create a momentum in favor of action. Deng recalled that it had been suggested that his title be changed to "Special Adviser on the Prevention of Genocide and Mass Atrocities"77 and also that he be made a "Representative" rather than a "Special Adviser." This was rejected, Deng 
maintained, by Russia, which led a campaign and mobilized many other countries to oppose any expansion of the OSAPG's mandate or further upgrade in its status. This, he argued, was because Russia feared that this would lead to rebel groups achieving disproportionate publicity for their cause and the creation of more pressure for some response from the Security Council. Nonetheless, while his mandate has not formally been expanded and there remains significant support among states for him to concern himself only with genocide, Deng stated, "I see my mandate in a broader sense ... I am not focusing on the legalistic definition of genocide and nor am I guided only by that narrow definition."78

\section{“A Waste of Time, and Energy, and Money"?}

Those directly connected with the OSAPG argued that it was too early to form an accurate appraisal of the office. They argued that it had really only been active since early 2008, as previously the part-time nature of the job, the lack of resources, and the minimal staff had hampered its effectiveness. Nonetheless, it was clear from the interviews with those outside the OSAPG that strong opinions as to the utility of the OSAPG had already been formed.

In his summation, Weiss asserted, "Frankly, I think this office is a waste of time, and energy and money." Evidence that the OSPAG has achieved any results is, according to Weiss, "totally lacking." 79 As noted previously, much of the blame for this has been attributed to the personality and style of Deng. While everyone interviewed spoke highly of Deng's intellect, character, and experience, all those not working directly with the OSAPG were critical of his appointment on the basis that his "behind-the-scenes" approach was ill-suited to this role. ${ }^{80} \mathrm{In}$ assessing this question it is necessary to reiterate the fact that preventative diplomacy by definition does not produce spectacular results. As Payam Akhavan notes "The Special Adviser has a thankless job. His success in early warning and prevention is necessarily measured in terms of what does not happen." 81 Additionally, the OSAPG's mandate commits it to act "without excessive publicity" and, therefore, while NGO's and others may believe that the OSAPG should act as an alarm bell, this is not actually its official remit. 82

It seems, however, that the utility of this "early warning" mechanism should be to act as the "alarm call" that many interviewees suggested. Behind-the-scenes diplomacy is not in itself inherently ineffective and clearly there is a place for just such a style. Yet, arguably, the UN secretary-general and the Red Cross already fulfill this role, and it does not seem logical to adopt this approach for this particular office. The office has not improved the information-gathering capacity of the UN and hence its utility lies in its capacity, as Crawshaw argued, to fast track information from other sources through the UN system. ${ }^{83}$ This would be most effectively done in a public way, meaning the Special Adviser would formally submit reports, give presentations, produce statements, etc., to maximize the impact of any particularly worrying information. If the information handled by the OSAPG is quietly and unofficially disseminated, this then has an impact on its capacity to create a momentum in favor of action. Deng acknowledged that states involved in activities deemed to be potentially genocidal, or likely to lead to genocide, are uncomfortable with discussing their situation in public for fear of external intervention. He additionally noted that states with either the capacity to intervene or the mandate to take action-or both in the case of the P5-are also happy to bury bad news for fear that they will be called upon to take action. How then, will Deng's "quiet approach" convince either the state involved in the deteriorating situation, or those states most 
likely to be called upon to respond, to take action to prevent an explosion of violence? None of the reports about the Rwandan genocide concluded that effective action would have occurred if the dire warnings issued before the genocide, by Ndiaye and Dallaire, for example, had been relayed through the UN system in a "quiet" manner. Indeed, by late April 1994, some three weeks after the Rwandan genocide began, representatives of the Czech Republic, Spain, New Zealand, and Argentina pressed the Secretariat to make public the information it had. The failure of the Secretariat to do so convinced these countries to look beyond the Secretariat for information and the information they eventually received convinced them that genocide was occurring and they publically called for more robust action, thereby significantly increasing the pressure on the P5 to act. As Nicolas Wheeler notes, the eventual public clamor to do something, particularly in France, eventually led to action being taken, albeit disastrously late and possibly in a counter-productive manner. ${ }^{84}$ To discuss deteriorating situations-so grave that they bear the hallmarks of potential genocideinformally with a view to maintaining cordiality cannot by definition generate a momentum in favor of action. Behind-the-scenes informal briefings leave no paper trail and thus facilitate the excuse, often offered after a crisis, that "we didn't know how bad things were." 85

Of course, generating momentum does not guarantee effective or timely action; the campaign to take robust action in Darfur was a huge success in terms of mobilizing international opinion and forcing the issue onto the agenda of the Security Council and yet it is now routinely argued that action taken in response to this campaign was manifestly inadequate. ${ }^{86}$ This has obvious implications for the approach adopted by Deng; if a massive campaign in favor of international action can fail to convince states to act then it seems fair to conclude that a "quiet approach" will be less likely to succeed. As Weiss remarked, "Logically speaking, if you can't even get people mobilized to do something in the midst of a crisis, the idea that somehow even before you have a crisis, they're all going to align and put money on it seems to me to be against the nature of human beings and certainly against the nature of the interstate system." 87 Of course, there are notable examples of effective international preventative action such as the UN Preventative Deployment Force stationed on the Macedonian/Serbian border from 1992 to 1999. Yet the history of the international response to intra-state crises undoubtedly suggests a reactive disposition despite the fact that proactive preventative action is not only likely to save lives, but is also significantly cheaper than action taken once violence has erupted. ${ }^{88}$

Deng, however, argued that while his methods were decried by NGOs, they had proven their effectiveness during his time as Representative of the United Nations Secretary-General on Internally Displaced Persons. Yet Weiss claimed that much of Deng's undoubted success in his previous role was a function of his semiindependence from the UN bureaucracy, as he was also an academic at the time. ${ }^{89}$ Deng himself acknowledged that while working on internally displaced persons, there were times when he exploited the freedom of his academic position to take certain actions that would have been impossible for a UN bureaucrat. ${ }^{90}$ Given that Deng no longer has the second hat as an academic, he cannot rely on the countertactic to the quiet approach he feels being a UN official requires him to adopt. In any event, Deng and his staff argued that the OSAPG had exercised significant influence at certain times, though this was necessarily largely impossible to see given that the work was done behind-the-scenes, and by definition it produces results you do not see. Nonetheless, none of those working with the OSAPG identified a 
particular case as an example of the OSAPG's effectiveness, and it is difficult not to conclude that this is indicative of the OSAPG's modest influence.

Yet, there is arguably a bigger concern regarding the efficacy of the OSAPG; the utility of the office is premised not on a belief in the benevolence of statesmen, but rather on an assumption that they fear shame. Stavropoulou claimed that a formal report by the OSAPG becomes part of the public record and serves as a deterrent to inaction as there will be a permanent record of the Special Adviser's warnings. She noted, "If, God forbid, another Rwanda happens and if this office has done its job properly, then it must have been able to identify what was going on, what was coming ... It will have brought this to the attention of the secretary-general and the Security Council and if no action is taken, then the responsibility and the accountability is very precisely located."91 Similarly, Wesamba argued that a report from the OSAPG created "obligations." When pressed to identify what these "obligations" were, given that there is no mention of any obligation incumbent upon the Security Council to even listen to the Special Adviser let alone act on his recommendations, Wesamba argued that these were obligations in the sense that they created normative pressure rather than legal compulsions to act. ${ }^{92}$ Deng himself argued, "[By establishing the OSAPG] we are sharpening our sensitivity to these issues and the resolve of the international community to act. Every time we say 'Never again!' and it happens again, the level of guilt rises and as the level of guilt rises, the level of resolve to do something about it before the next time increases." 93 Given recent history, this would appear to be a perspective born more from hope than experience. After the genocide in Rwanda, statesmen around the world lamented their response and "Never Again!" was once again widely and loudly proclaimed. Yet, in his assessment of the response to the crisis in Darfur, Kofi Annan noted, "We were slow, hesitant, uncaring and we had learnt nothing from Rwanda."94 This clearly doesn't correlate with Deng's claim. States appear to have little compunction about ignoring or equivocating about a looming or actual genocide unless they have significant national interests involved. National interests are not immutable, of course, and there is some evidence that pressure to act, either from NGOs, domestic publics or UN organs, can influence states to alter their stance on a particular issue. Nonetheless, it seems unlikely that an office that the Security Council is empowered to ignore, led by a Special Adviser who has chosen to adopt a "quiet approach" and restrained from speaking out by a cautious secretary-general, will be able to generate the requisite pressure to convince those states with the power and authority to mandate preventative action to fundamentally alter their foreign policies.

\section{Conclusion}

The UN internal inquiry into the organization's response in 1994 presented fourteen recommendations for UN reform, the fourth of which stated, "The early warning capacity of the United Nations needs to be improved though better cooperation with outside actors including NGOs and academics as well as within the Secretariat."95 The OSAPG appears to be a tangible manifestation of this recommendation and on that basis its establishment is to be welcomed. It has been championed by both the current and former secretary-general as a highly significant innovation and the importance of its mandate is obvious. To date, however, it has not been subjected to focused academic analysis and information about the working of the office and perceptions as to its effectiveness are largely absent from academic literature. This article has sought to address this gap and is based on a unique series of interviews with leading figures within the OSAPG and informed observers outside it. The 
findings of this research are illustrative of the views of NGOs and the OSAPG itself. It would be additionally instructive to undertake research into the perspectives of various nations on the OSAPG and, though this is beyond the scope of the current article, it is a future aim.

Deng recalled that when he was asked to take up the position of Special Adviser he felt it was "a call of duty and a service to humanity that I could not take lightly," though he admitted, "I quickly went from being flattered and honored, to worrying 'what have I got myself into in taking on this huge responsibility?" 96 Deng and his staff's commitment to the OSAPG appears to be beyond question and their genuine enthusiasm for the OSAPG can only be beneficial. This enthusiasm, however, is not widely shared.

The "quiet approach" adopted by Deng does have some support and should not be disregarded as fundamentally flawed. ${ }^{97}$ Nonetheless, while behind-the-scenes diplomacy can be effective, it is criticized as an inappropriate method for this office. All those interviewed working outside the OSAPG argued that the Special Adviser should become a much more public figure and act as a vocal warning mechanism. Yet, given the nature of the mandate, a compromise between Deng's approach and that advocated by the interviewees would arguably be best advised. Without becoming a media-friendly mouthpiece, the Special Adviser could maintain a demeanor of calm analysis, rather than adopting a combative, accusatory approach based on a worse-case-scenario reading of information. He could increase the profile of the OSAPG by seeking to exploit its capacity to address the Security Council. Failure to avail himself of this aspect of the mandate constitutes a lost opportunity to raise the profile of the OSAPG, but more importantly, engaging more formally with the Council creates a formal record of warnings issued to the P5, which could undermine any subsequent claims that information about a particular situation was lacking. This is not to support the claims made by Stavropoulou that the OSAPG could somehow "shame" the P5 into acting, but it does constitute the basis for generating some degree of leverage; action of this type by the OSAPG will be highly unlikely in and of itself to convince the Security Council to take preventative action, but in conjunction with other factors, it could contribute to building momentum. Acting more in the public sphere would additionally raise the profile of the OSAPG within the UN itself, where it is clear there is a lack of information about the office. Many of those who do know of its existence, evidently harbor a degree of hostility toward it.

The central issue in the quest to prevent genocide is the mobilization of political will. The UN's inquiry into the Rwandan genocide claimed that the "fundamental failure" was "a persistent lack of political will."98 Overcoming this barrier constitutes an enormous task that should not be deemed the responsibility of the OSPAG alone. The interviews conducted with staff at the OSAPG highlighted that states are reluctant to discuss genocide-actual or apprehended-for fear that they may be called upon to act. Clearly this disposition among states creates a far from propitious context in which the OSAPG is tasked with executing its mandate. The fact that the Special Adviser cannot automatically address the Security Council is perhaps indicative of the P5's desire to manage the flow of information it is formally exposed to. The former Special Adviser-Juan Mendez-suggested reforming the mandate of the OSAPG so that the right to address the Council could not be vetoed and this would be a potentially highly significant strengthening of the OSAPG's powers. Yet, even with this reform of the OSAPG's mandate, there is no guarantee that the spectacle of inertia in the face of mass tragedy, which has so degraded the status of the UN in the past, will not happen again. As Secretary-General Ban Ki-Moon noted 
in his 2009 report, "[T]he crucial element in the prevention of genocide remains responding to concerns, once these have been communicated." 99 The current secretarygeneral has expressed his commitment to the office and there appears to be no danger that it will be dissolved in the near future. Whether the OSAPG can ever be effective given its restrictive mandate, the style of the current incumbent, and the perennial problem posed by the lack of political will, especially amongst the P5, will become more evident in the next five years as crises inevitably arise and the OSAPG's influence_or lack thereof-becomes more evident.

\section{Notes}

1. Thomas Weiss, "Halting Genocide: Rhetoric versus Reality," Genocide Studies and Prevention 2, no. 1 (2007): 7.

2. Bertrand. G. Ramcharan, Preventive Diplomacy at the UN (Bloomington: Indiana University Press, 2008), 180; David Hamburg, Preventing Genocide (Boulder, CO: Paradigm, 2008), 226.

3. See Michael Barnett, Eyewitness to a Genocide (Ithaca, NY: Cornell University Press, 2002), 130-52.

4. Report of the Independent Inquiry into the Actions of the United Nations during the 1994 Genocide in Rwanda, UN Security Council, UN Doc. S/1999/1257 (15 December 1999), 54-55.

5. Report of the Secretary General on the Prevention of Armed Conflict, UN Security Council, UN Doc. A/55/985-S/2001/574 (7 June 2001), 12.

6. Hamburg, Preventing Genocide, 224.

7. "Letter dated 12 July 2004 from the Secretary-General to the President of the Security Council," Kofi Annan, UN Doc. S/2004/567 (12 July 2004), http://daccessdds.un.org/doc/ UNDOC/GEN/N04/424/63/PDF/N0442463.pdf?OpenElement.

8. The exception being Payam Akhavan, Report on the Work of the Office of the Special Adviser of the United Nations Secretary-General on the Prevention of Genocide (Montreal: McGill University, Faculty of Law, 7 November, 2005), www.un.org/preventgenocide/ adviser/public.shtml (accessed 25 September 2009). This report, commissioned by the OSAPG, constitutes a very comprehensive and uniquely focused analysis of the OSAPG. It is, however, some four years out of date and thus does not provide information on the significant recent changes to the status and personnel within the OSAPG that took place in 2007.

9. The author would like to thank the Nuffield Foundation for providing a research grant for these interviews.

10. See, for example, Henry R. Huttenbach, "From the Editors: Genocide Prevention: Sound Policy or Pursuit of a Mirage?" Journal of Genocide Research 10, no. 4 (2008): 471-73. Additionally the eminent historian Roland Wright speculates that our evolution is a function of genocide and thus the disposition to commit genocide may be intrinsic to our genetic makeup. Roland Wright, A Short History of Progress (Edinburgh: Canongate, 2006), 25.

11. Aidan Hehir, Humanitarian Intervention (Hampshire: Palgrave Macmillan, 2010), 181.

12. See for example, Christopher Clapham, "Rwanda: The Perils of Peacemaking," Journal of Peace Research 35, no. 2 (1998), 200; John Mayall, "Humanitarian Intervention and International Society: Lessons From Africa" in Humanitarian Intervention and International Relations, ed. Jennifer Welsh (Oxford: Oxford University Press, 2006), 136; Nicholas Wheeler, Saving Strangers: Humanitarian Intervention in International Society (Oxford: Oxford University Press, 2002), 214; Anne Orford, Reading Humanitarian Intervention (Cambridge: Cambridge University Press, 2003), 85.

13. Nonetheless, I did put this view to Professor David Hamburg. His response was that the international engagement with Rwanda prior to the genocide was "trivial," stating that "what was there in Rwanda [prior to the outbreak of violence] was all chaotic. They 
didn't know what to do. Yeah, there were people there, but it was not well thought out, well organized ... They made an effort and good for them. They made an effort. It was a poorly informed effort, poorly coordinated effort, and it had a lot of undermining influences, from France, from Belgium, from the United States ... There's no guarantee [that preventative diplomacy works]; it's the best you can do." Interview with David Hamburg, Chairman of the OSAPG Advisory Committee, New York, 18 August 2009.

14. Interview with Heather Sonner, International Secretariat of the Institute for Global Policy, New York, 18 August 2009.

15. Interview with Steve Crawshaw, Human Rights Watch's United Nations Advocacy Director, New York, 17 August 2009.

16. Interview with Nicola Reindorp, Director of Advocacy at the Global Centre for the Responsibility to Protect, New York, 19 August 2009.

17. Ibid.

18. Interview with Maria Stavropoulou, Political Affairs Officer, OSAPG, New York, 21 August 2009.

19. For details of the information contained in this cable, see Romeo Dallaire, Shake Hands with the Devil (London: Arrow Books), 142-46. The full text of the cable is available at http://www.pbs.org/wgbh/pages/frontline/shows/evil/warning/cable.html (accessed 17 September 2009).

20. Interview with Steve Crawshaw, 17 August 2009. This is not a perspective shared by all, however. According to Michael Barnett, UN officials with the capacity to influence events failed to meet their responsibilities. The Department of Peacekeeping Operations failed to inform the Security Council about Dallaire's cable warning of imminent mass ethnic killings; Secretary General Boutros Boutros-Ghali was "positively anaemic," and within the Secretariat, civil servants were, he claims, "timid, indecisive, and deceitful." The UN, he concludes, "responded to the genocide with willful ignorance and indifference," Barnett, Eyewitness to a Genocide, 3-4.

21. Interview with Heather Sonner, 18 August 2009.

22. Interview with Nicola Reindorp, 19 August 2009.

23. Interview with Francis Deng, Special Adviser on the Prevention of Genocide, New York, 20 August 2009.

24. Ibid.

25. Ibid.

26. For further information on this report, and the UN's reaction to it, see Report of the Secretary-General on the Implementation of the Five Point Action Plan and the Activities of the Special Adviser on the Prevention of Genocide, UN Doc. E/CN.4/2006/84 (9 March 2006), 17.

27. Interview with Francis Deng, 20 August 2009.

28. Interview with Maria Stavropoulou, 21 August 2009.

29. Interview with Professor Thomas Weiss, Director of the Ralph Bunche Institute for International Science, New York, 19 August 2009.

30. Gareth Evans is a prominent advocate of the idea of a "Responsibility to Protect" and a member of the OSAPG Advisory Committee.

31. Interview with Thomas Weiss, 19 August 2009.

32. Interview with Heather Sonner, 18 August 2009.

33. Interview with Maria Stavropoulou, 21 August 2009.

34. Interview with David Hamburg, Chairman of the OSAPG Advisory Committee, 18 August 2009.

35. Ibid.

36. Interview with Francis Deng, 20 August 2009.

37. Interview with Maria Stavropoulou, 21 August 2009.

38. One possible explanation for this is the extent to which UN organs, according to Michael Barnett, have become highly subservient to the "whims of the volatile Great Powers." In the face of their apparent inability to act without the consent of the Great Powers, UN 
bodies have consciously constructed a self-image whereby they are "servants and subordinates" and adopted a modus operandi orientated toward "a highly cautious approach." Barnett, Eyewitness to a Genocide, 10.

39. Interview with Thomas Weiss, 19 August 2009.

40. Interview with Heather Sonner, 18 August 2009.

41. Interview with Nicola Reindorp, 19 August 2009.

42. Interview with Francis Deng, 20 August 2009.

43. Ibid.

44. Ibid.

45. Stavropoulou did say that one of the most significant achievements was rebuilding the relationship with the Security Council, which had broken down completely during the tenure of Juan Mendez. Interview with Maria Stavropoulou, 21 August 2009.

46. Interview with Steve Crawshaw, 17 August 2009.

47. Interview with Heather Sonner, 18 August 2009.

48. Interview with Nicola Reindorp, 19 August 2009.

49. Interview with Maria Stavropoulou, 21 August 2009.

50. Ibid.

51. Interview with Francis Deng, 20 August 2009.

52. Interview with Castro Wesamba, Political Affairs Officer OSAPG, New York, 21 August 2009.

53. Interview with Heather Sonner, 18 August 2009.

54. Interview with David Hamburg, 18 August 2009. For more information on the specifics of the Council's refusal to allow Mendez access in October 2005, see Akhavan, Report on the Work of the Office of the Special Adviser of the United Nations Secretary-General on the Prevention of Genocide, 6; and, Lee Feinstein, Darfur and Beyond: What is Needed to Prevent Mass Atrocities, Council on Foreign Relations, Council Special Report No. 22 (Washington, DC: Brookings Institution Press, 2006), 15-16.

55. Interview with Francis Deng, 20 August 2009.

56. Interview with Steve Crawshaw, 17 August 2009.

57. Stavropoulou in fact noted, "I don't think anybody wants [the right to address the Council] to be automatic." Interview with Maria Stavropoulou, 21 August 2009.

58. United Nations Association of the United States of America, Strengthening the United Nations' Capacity to Prevent Genocide: A Project Report of the United Nations Association of the United States of America on Supporting the Special Adviser to the SecretaryGeneral on the Prevention of Genocide (New York: UNA-USA, 2006), 3. This, however, is not a view shared by David Hamburg; he claimed that the Council was dominated by particular interests and argued, "the more you can avoid the Security Council the better." Interview with David Hamburg, 18 August 2009.

59. J. Dieter, "Humanitarian Intervention and the Prevention of Genocide," Journal of Genocide Research 10, no. 2 (2008): 301.

60. Interview with Maria Stavropoulou, 21 August 2009.

61. Ibid.

62. Interview with Francis Deng, 20 August 2009.

63. Interview with Castro Wesamba, 21 August 2009.

64. Interview with Francis Deng, 20 August 2009.

65. Ibid.

66. Stavropoulou stated, "[At meetings of states where OSAPG raises concerns], the first question always is, 'Why do you think that this is genocide?,' because people, no matter how often you repeat what the work of the office is all about, they always think that you're making a pronouncement about genocide." Interview with Maria Stavropoulou, 21 August 2009.

67. Barnett, Eyewitness to a Genocide, 4.

68. Ibid, 5 .

69. Ibid, 10. 
70. Interview with Thomas Weiss, Director of the Ralph Bunche Institute for International Science, 19 August 2009.

71. Interview with Thomas Weiss, 19 August 2009.

72. Interview with Maria Stavropoulou, 21 August 2009.

73. Annual Report of the United Nations High Commissioner for Human Rights and Reports of the Office of the High Commissioner and the Secretary-General: Efforts of the United Nations System to Prevent Genocide and the Activities of the Special Adviser to the Secretary-General on the Prevention of Genocide. Report of the Secretary-General, Human Rights Council, UN Doc. A/HRC/10/30 (18 February 2009), 13.

74. Interview with Castro Wesamba, 21 August 2009. Wesamba also argued that the Burundian government had engaged indirectly with the OSAPG, but the week of the visit did not suit due to "internal dynamics" related to the government's dealings with the armed opposition group, the Forces for National Liberation.

75. Juan Mendez, Report of the Special Adviser on the Prevention of Genocide: Visit to Darfur, Sudan, 19-26 September 2005 (4 October 2005), http://www.h-net.org/ genocide/ docs/mendez-report.pdf (accessed 25 September 2009).

76. Interview with Francis Deng, 20 August 2009.

77. Curiously, the title on the door of the office where the OSAPG is based reads "Special Adviser of the Secretary-General on the Prevention of Genocide and Mass Atrocities."

78. Interview with Francis Deng, 20 August 2009.

79. Interview with Thomas Weiss, 19 August 2009.

80. Interestingly, David Hamburg noted that Deng was the first choice of the Advisory Committee when Mendez signaled his desire to relinquish the post. Interview with David Hamburg, 18 August 2009.

81. Akhavan, Report on the Work of the Office of the Special Adviser of the United Nations Secretary-General on the Prevention of Genocide, 11.

82. "Letter dated 12 July 2004 from the Secretary-General to the President of the Security Council," 2.

83. Interview with Steve Crawshaw, 17 August 2009.

84. Nicholas Wheeler, Saving Strangers, 236-41.

85. Indeed, this was President Clinton's excuse for his administration's lack of action in 1994. During a visit to Rwanda in 1998 he stated, "It may seem strange to you here ... but all over the world there were people like me sitting in offices, day after day after day, who did not fully appreciate the depth and the speed with which you were being engulfed by this unimaginable terror." See "Clinton in Africa: Clinton's Painful Words of Sorrow and Chagrin," New York Times, 26 March 1998. This excuse-that the US simply didn't know how bad things were-has been refuted by many; see, for example, Rory Carroll, "US Chose to Ignore Rwandan Genocide," The Guardian, 31 March 2004; S. Power, "By-Standers to Genocide," The Atlantic, September 2001.

86. See for example, Human Rights Watch, Human Rights First, and Save Darfur, "Rhetoric vs. Reality: The Situation in Darfur" (December 2008), http://www.hrw.org/sites/default/ files/related_material/darfur1208.pdf.

87. Interview with Thomas Weiss, 19 August 2009.

88. See Carnegie Commission on Preventing Deadly Conflict, Preventing Deadly Conflict: Final Report (New York: Carnegie Corporation, 1997), http://www.wilsoncenter.org/subsites/ccpdc/ pubs/rept97/finfr.htm.

89. Interview with Thomas Weiss, 19 August 2009.

90. Interview with Francis Deng, 20 August 2009.

91. Interview with Maria Stavropoulou, 21 August 2009.

92. Interview with Castro Wesamba, 21 August 2009.

93. Interview with Francis Deng, 20 August 2009.

94. Quoted in David Fisher, "Humanitarian Intervention," in The Price of Peace, ed. Charles Reed and David Ryall (Cambridge: Cambridge University Press, 2007), 103. 
95. Report of the Independent Inquiry into the Actions of the United Nations during the 1994 Genocide in Rwanda, Security Council, UN Doc. S/1999/1257 (15 December 1999), 53.

96. Interview with Francis Deng, 20 August 2009.

97. For a defense of this approach, see Ramcharan, Preventive Diplomacy at the UN, 184.

98. Report of the Independent Inquiry into the Actions of the United Nations during the 1994 Genocide in Rwanda, 3.

99. Annual Report of the United Nations High Commissioner for Human Rights and Reports of the Office of the High Commissioner and the Secretary-General, 17. 